Discussion Paper No. 16-070

Rockets and Feathers: Asymmetric Pricing and Consumer Search Evidence from Electricity Retailing

Sven Heim

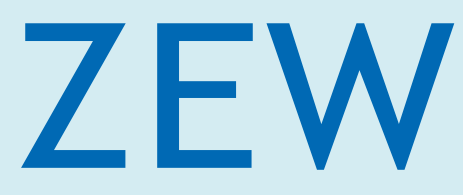

Zentrum für Europäische Wirtschaftsforschung $\mathrm{GmbH}$ Centre for European Economic Research 
Discussion Paper No. 16-070

\title{
Rockets and Feathers: Asymmetric Pricing and Consumer Search - Evidence from Electricity Retailing
}

\author{
Sven Heim
}

Download this ZEW Discussion Paper from our ftp server:

http://ftp.zew.de/pub/zew-docs/dp/dp16070.pdf

Die Discussion Papers dienen einer möglichst schnellen Verbreitung von neueren Forschungsarbeiten des ZEW. Die Beiträge liegen in alleiniger Verantwortung der Autoren und stellen nicht notwendigerweise die Meinung des ZEW dar.

Discussion Papers are intended to make results of ZEW research promptly available to other economists in order to encourage discussion and suggestions for revisions. The authors are solely responsible for the contents which do not necessarily represent the opinion of the ZEW. 


\title{
Rockets and Feathers: Asymmetric Pricing and Consumer Search - Evidence from Electricity Retailing
}

\author{
Sven $\operatorname{Heim}^{\dagger}$
}

\begin{abstract}
Recent theories aim at explaining asymmetric cost pass-through by different consumer search efforts depending on whether prices increase or decrease. This paper investigates the relation between price adjustments and consumer search intensity for the German electricity retail market utilizing a unique panel dataset comprising retail electricity prices and consumer search queries on price-comparison websites. The main findings are 1) consumers search less when prices fall than when they rise, 2) costs are passed-through asymmetrically and 3) controlling for search intensity particularly eliminates the asymmetry. This suggests that 'Rockets and Feathers' patterns may be explained by an omitted variable bias.
\end{abstract}

Keywords: Information, Cost Pass-through, Consumer Search, Rockets and Feathers JEL Codes: D83, L11

\footnotetext{
† ZEW Centre for Economic Research Mannheim. Email: heim@zew.de. I gratefully acknowledge ene’t (enet.eu) for providing extensive data on search queries as well as prices and cost information. I thank Acxiom (acxiom.de) for providing detailed data on structural household characteristics. The paper benefitted from comments by Georg Götz, Klaus Gugler, Michael Hellwig, Ulrich Laitenberger, Matthew Lewis, Bettina Peters, Dennis Rickert, Philipp Schmidt-Dengler, Joel Stiebale and Michael Waterson as well as presentations and discussions at the Jornadas de Economia Industrial 2016 and the EARIE 2016 conferences. Financial support by the State Government of Baden-Württemberg, Germany, through the research program 'Strengthening Efficiency and Competitiveness in the European Knowledge Economies' (SEEK) is gratefully acknowledged.
} 


\section{Introduction}

Prices rise more strongly (or quickly) when costs increase than they fall when costs decrease. This stylized fact is frequently referred to as 'rockets and feathers' pricing and arguably gasoline retail markets present the most prominent example for such asymmetric cost pass-through patterns (Bacon, 1991; Borenstein et al., 1997). The non-competitive market structure in these (local) markets suggests that collusion may be a plausible explanation for the 'rockets and feathers' phenomenon. On these grounds, Borenstein et al. (1997) argue that 'prices are sticky downward because when input prices fall the old output price offers a natural focal point for oligopolistic sellers'. ${ }^{1}$

However, in a famous article Peltzman (2000) analysed cost pass-through in 242 markets and documented asymmetry in two out of three cases. Counterintuitively to the collusion argument, he observes asymmetric cost pass-through to the same extent also in atomistic markets. Thus, collusion may not always be a convincing explanation for 'rockets and feathers' patterns. This finding led Peltzman to draw a very strong conclusion by stating that the observed asymmetry points to a gap in an essential part of economic theory.

Seeking for alternative channels for asymmetric cost transmission other than collusion in order to fill this gap some more recent theoretical approaches aimed at relating price adjustments to consumers' search efforts (Cabral and Fishman, 2008; Yang and Ye, 2008; Tappata, 2009, Lewis, 2011; Cabral and Gilbukh, 2015). Though these models differ in their setup they all share similar predictions: either consumers search more when prices are high and less when prices are low (Yang and Ye, 2008, Tappata, 2009)

\footnotetext{
1 An excellent literature survey on asymmetric cost pass-through is from Meyer and von CramonTaubadel (2004).
} 
or consumers search more when prices rise and less when prices fall (Cabral and Fishman, 2008; Lewis, 2011; Cabral and Gilbukh, 2015).

The underlying intuition is fairly simple: consumer search affects the competitive environment faced by a firm. If prices for a good or service are high (or increase) consumers are more likely to engage in search for alternative suppliers than if prices are low (or decrease). Thus, a consumer's current supplier finds herself in a more competitive environment when prices are high (or rise) and consumers search more compared to a situation where prices are low (or fall) and consumers search less and are less aware of cheaper alternative suppliers. Putting it differently, not the absolute number of competitors is relevant in determining the level of competition but the number of competitors with prices known to the consumer. Hence, search intensity is nothing else than a measure of competitive pressure. Or as Tappata (2009) puts it: 'Consumers' search decisions affect the elasticity of the expected demand faced by firms and therefore their cost pass-through.'(Tappata, 2009).

These theories suggest that search intensity may provide an explanation for asymmetric cost pass-through. If this prediction proofs to be right than Peltzman's claimed gap in economic theory would be nothing else than a violation of the complete information assumption: for the law of one price - as known from the standard homogeneous goods Bertrand model - to be valid, consumers must be aware of all offered prices for the product (Stigler, 1961). Therefore, an empirically estimated asymmetric cost pass-through rate may point towards an omitted variable bias due to the omission of consumer information rather than a gap in economic theory.

In this context I empirically investigate the potential link between cost changes, price adjustments and consumer search intensity utilizing a rich and unique panel data set on prices, costs and consumer search intensity in the German retail electricity market. The market provides excellent properties for the analysis. First, electricity is a classic 
example for a homogeneous good ${ }^{2}$. Second, there are many local markets with different prices and costs. More precisely, there are 777 local incumbents in Germany, each serving a separate supply area. But costs and thus prices differ even within the same supply area as will be explained later in the data section. This provides substantial regional variation in cost and price developments. Third, since the market was liberalized in 1999 (when the EU Directive 96/92/EC came into force) customers can freely choose their electricity supplier. For instance, in 2014 a household could choose between 73 and 198 providers for retail electricity (155 on average), depending on its location. This makes collusion unlikely.

Fourth, there substantial search costs apparently exist in the market: even though a standard two-person household with $3,500 \mathrm{kWh}$ yearly electricity consumption would have saved 196 Euro by switching from the former incumbents' standard tariff to the cheapest local supplier, $78 \%$ of all German households were still supplied by the former incumbent in 2014. ${ }^{3}$ This price dispersion accounts for approximately $20 \%{ }^{4}$ The violation of the 'law of one price' may be explained by the existence of search costs as theory (e.g. Stigler, 1961, Varian, 1980, Stahl, 1989, Burdett and Judd, 1993, Janssen and Moraga-González, 2004, Chandra and Tappata, 2011) and empirical studies (e.g. Sorensen, 2000, Baye et al., 2004, Chandra and Tappata, 2011, Giuletti et al., 2014, Hortacsu et al., 2015, Pennersdorfer et al., 2015, Gugler et al., 2016) suggest. In general, there are two further candidate explanations for the observed price dispersion

\footnotetext{
${ }^{2}$ There may be some form of product differentiation, such as certification of a tariff with a "green" label etc. In my sample, less than $4 \%$ of all search queries relate to tariffs with eco-labels. Therefore, in the present application I exclude search queries that exclusively consider eco-label tariffs in order to rule out pricing effects from such a form of product differentiation. However, the results remain fully robust when these searches are also included.

${ }^{3}$ Bundesnetzagentur (Federal Network Agency) and Bundeskartellamt (Federal Cartel Office (2014) Monitoringreport.

${ }^{4}$ For comparison: the costs for $3,500 \mathrm{~kW}$ electricity estimated from whole sale electricity prices only account for an average $15 \%$ of the retail electricity price charged by the incumbents.
} 
which may also contribute to the observed consumer inertia, namely switching costs and brand effects. In the present case, switching costs are not likely to be relevant as a) the switching process is an automated process and conducted by the chosen new electricity retailer and b) the cancellation period for the incumbents' base tariffs is only two weeks by law. Brand effects are also not likely to play a substantial role in the market (see Giuletti et al, 2012, or Hortacsu et al, 2015). There is no reason to assume that the incumbent supplier provides a higher security of supply as the incumbent has the legal obligation to guarantee a continuous provision of electricity to the consumers. ${ }^{5}$ Therefore, if an entrant goes bankrupt the bankrupt firm's customers experience a seamless transition to the local incumbent's standard tariff without an interruption of electricity supply and without penalizing these consumers. ${ }^{6}$

Thus, above market characteristics suggest that if costs are passed-through asymmetrically than collusion may not be a very reasonable explanation but search costs may be. ${ }^{7}$ Finally, the market provides an excellent robustness check for the analysis. As initially all consumers are automatically assigned to the (former) incumbent the shares of informed and uninformed consumers are heterogeneous between incumbents and entrants. This is important: if a consumer never searches the incumbent is a monopolist for this consumer. However, for each searching consumer the incumbents market changes to perfect competition exactly in the moment the

\footnotetext{
${ }^{5}$ In this regard, Hortacsu et al. (2015) estimate that there is a perceived brand effect consumers attach to the incumbent. However, the effect diminishes rapidly in the first years of retail choice and is already very small at the end of their observation in 2006. Therefore, in my observation period (2011 to 2014) the majority of the consumers should be aware of the statutory safety net provided by the incumbents.

6 Indeed, two of the bigger alternative providers went bankrupt in 2011 (Teldafax) and 2013 (Flexstrom), respectively.

${ }^{7}$ Furthermore, a household's demand for electricity can be described as perfectly inelastic in the shortterm which excludes convexity of the demand curve as a candidate explanation for potential asymmetric pass-through (Ritz, 2015).
} 
consumer enters the online price comparison site. By contrast, each consumer that receives electricity from one of the entrants had to actively engage in searching before leaving the incumbent and signing with the entrant. Thus, while the incumbent's customers are generally uninformed (otherwise they would generally switch to one of the much cheaper entrants) those of the entrants are much more informed (see Gugler et al. 2016). As a consequence, if consumers' search intensity actually affects passthrough rates then this should only hold for the incumbents while entrants should be unaffected by consumer search intensity or at least not affected to the same extent as the incumbent.

To my knowledge this is the first empirical paper that directly relates cost passthrough to consumer search patterns. It is also the first paper that utilizes a direct measure of consumer search intensity in a panel data context.

\section{Empirical Strategy}

The analysis is conducted in three steps. First, I investigate whether consumers' search efforts are a function of prices and price movements, respectively. i.e. do consumers actually search more when prices are high (increase) than when they are low (decrease)? Subsequently, I analyse whether there is evidence for an asymmetric cost pass-through in the electricity retail market using conventional methods to evaluate potential cost pass-through asymmetries. Eventually, I check whether consumer search intensity has an impact on price adjustments. Summarized my findings are 1) consumers search more when prices are high or increase than when prices are low or decrease, 2) costs are passed-through asymmetrically in a 'rocket and feathers' manner in models which do not consider the potential impact of consumer search intensity on price adjustments and 3) considering consumer search intensity particularly eliminates the asymmetry in the pass-through rates. 
The examination of the first step in this paper is inspired by Lewis and Marvel (2011) who analyse gasoline prices in the US and find that on average the level of consumer search is higher when prices increase than when they decrease. However, there are also some differences. First, Lewis and Marvel only regress the level of search intensity rather than changes in search intensity on gasoline price adjustments. Thus, they do not directly measure the adjustments of search intensity to price changes. Also, I consider the likely endogeneity between consumer search and pricing strategies using regional variation in exogenous cost components (such as grid charges) to instrument for prices while Lewis and Marvel (2011) instrument for national average gasoline price changes through wholesale price changes which is potentially related to demand/quantity. Next, my data enable me to take advantage of spatial variation while Lewis and Marvel (2011) use a time series with national aggregated prices and thus do not consider any spatial differences. Finally, the Lewis and Marvel (2011) data on gasoline prices rely on consumer reporting and they do not actually observe prices for all stations. This might induce a bias in terms of an oversampling of low prices as the authors acknowledge as these are the prices that the reporting consumers actually pay. Despite these differences, my findings in the first step provide additional evidence of similar behaviour to what Lewis and Marvel (2011) are seeing, i.e. search intensity is high (increases) when prices are high (increase) and low (decreases) when prices are low (decrease). ${ }^{8}$

In the second step I apply a common approach to examine asymmetric cost-passthrough (e.g. Borenstein et al., 1997) by splitting cost changes into cost increases and decreases and regressing price changes on the two split cost variables.

Most important is the third step where I include consumer search intensity into the model to test whether this contributes to the explanation of price adjustments and

\footnotetext{
${ }^{8}$ Hortacsu et al. (2015)
} 
pass-through symmetry. Again, endogeneity of search is considered through instrumental variables.

I will first describe the data and identification strategy in section 2, followed by the empirical models and the results in section 3 and 4 . Section 5 concludes.

\section{Data and Variables}

I utilize a unique and detailed panel data set on consumer search activities, retail electricity prices and cost components from ene't. Acxiom provides data on structural household characteristics. The Acxiom data are on yearly level while the ene't data are monthly (costs and prices) and minutely timestamps (search queries). I aggregate the ene't data also on yearly level as a typical electricity contract lasts twelve month and even if the contract can be terminated on a monthly basis most retailers offer a substantial switching bonus which they only pay out after twelve months. Therefore, I assume that an average household does not search more than once a year. The data span the years 2011 to 2014. As prices, costs and search intensity varies regionally the spatial data resolution is on zip code level (8,224 zip codes).

\section{Measure of consumer search intensity}

I construct a measure for consumer search intensity from the ene't data which contains detailed information from click data spanning the period from March 2011 to December 2014. The data base covers all search queries conducted on several price comparison platforms including Toptarif.de (top tariff), Stromtipp.de (power tip), Energieverbraucherportal.de (energy consumption portal) and mut-zum-wechseln.de (courage-to-change). For each query I observe the timestamp of the query, the zip code for which the offered electricity tariffs were requested, the (expected) yearly consumption entered into the search mask, consumer type (household or industrial customer), the search criteria, e.g. indicating whether the consumer is only interested 
in electricity tariffs with an eco-label as well as a search session ID indicating the order of the queries of each searching consumer. Exemplary, a screenshot of the search mask from Toptarif.de is available in the Appendix (Figure 2). In sum I have information on 35,855,071 search queries and 17,302,530 search sessions from which 16,778,214 are conducted by households and the remaining 524,316 by industrial customers. I will focus on households and therefore exclude the search queries from industrial consumers.

From the data I construct a measure for consumer information as follows: Because many searchers conduct several search queries within a search session (e.g. comparing prices for different levels of consumptions and different tariffs) I only consider the number of search sessions and refer to a consumer conducting a search session as being fully informed regardless of the depth of her search activity. I then aggregate the search sessions within a zip code area on yearly basis and subsequently divide this value by the number of households within the same zip code area in the corresponding year. Because I observe some extreme outliers in some zip code areas apparently resulting from price comparing bots or the curse of data crawling researchers I drop the $2 \%$ of the observations with the highest values from the data. The measure for consumer search intensity can be written as

$$
\mu_{i t}=\frac{N_{i t}^{S S}}{N_{i t}^{H H}}
$$

with $\mu$ describing search intensity, $N^{S S}$ the number of search sessions, $N^{H H}$ the number of households and subscripts $i$ and $t$ represent zip codes and years. Searches on online price comparison sites should work as an excellent proxy for the general consumer 
search intensity as the vast majority of consumers uses online price comparison site to switch their electricity provider. ${ }^{9}$

Price

Retail electricity prices vary significantly regionally. There are 777 incumbents in Germany serving their local supply areas (mostly municipal utilities, so called Stadtwerke), however, their prices also vary within the same supply area due to finer cost variation. I therefore go down to zip code levels. In 2014 the electricity bill for a 2 person household with $3,500 \mathrm{kWh}$ yearly electricity consumption in the incumbent's base tariff was on average 1004 euro, varying from 761 and 1204 Euro, depending on the zip code of the household. The cheapest entrant charged on average 808 Euro per year. Prices in each zip code are observed on a due date each month and subsequently transformed into year averages.

In the main application I will focus on a standard two-person household with on average $3,500 \mathrm{kWh}$ yearly consumption. However, all results presented in the paper are fully robust to alternative household sizes such as a one-person household with 2,000 kWh consumption or a four-person household with an average consumption of 5,000 kWh per year.

\section{Costs}

Costs differ substantially over zip codes due to several regionally varying cost components, particularly the grid charges and the concession fee. Grid charges are paid by the electricity provider to the respective system operator and thus vary over the 873 German distribution grids (basically the former incumbents' supply areas,

\footnotetext{
${ }^{9}$ According to a survey $80 \%$ of the switchers searched online for alternative providers (A.T. Kearney, 2012)
} 
however, some former incumbents had to sell their grids in due course of unbundling legislations). The concession fee has to be paid by the system operator to the municipality for the right to install and operate electric cables on public roads and therefore varies on municipality level (12,308 municipalities). In 2014 costs for 3,500 kWh electricity varied on average around 33 Euro (maximum 240 Euro) over the 8,224 zip codes. These costs also vary substantially over time. From 2013 to 2014 the change in these variable costs varied between a 90 Euro decrease and a 85 Euro increase over all zip codes, 17 Euro on average.

In addition there are cost components without regional but also with time variation. These are in particular the wholesale electricity price and the EEG cost apportionment - a fee consumers have to pay per MW in order to subsidize renewable energies according to the renewable energy act (Erneuerbare Energien Gesetz, EEG). For the wholesale price I use the yearly average of the Phelix Base one year ahead futures which are available from the EEX (European Energy Exchange). ${ }^{10}$ The costs for 3,500 $\mathrm{kWh}$ at the wholesale markets where approximately 156 Euro in our observation period and thus accounted for less than $16 \%$ of the incumbents' average prices. I also consider value added taxes, electricity taxes, measuring fees and CHP surcharges. From these cost data I compute a) the regionally varying costs and b) the total costs per zip code and year for incumbents and entrants. ${ }^{11}$

Figure 3 to Figure 5 in the Appendix provides an overview on the spatial distribution of prices, costs and search intensity. Figure 6 and Figure 7 in the Appendix illustrate the distribution of cost changes for each year.

\footnotetext{
10 However, all results reported in the paper are robust to sensible alternative definitions of the wholesale prices such as yearly averages of the Phelix day-ahead spot prices and a also a mixture of both (Phelix Base Spot + Phelix Base future 1 year) $/ 2$.

11 Total costs for incumbents and entrants differ due to differences in value added taxes from different prices.
} 
Structural household characteristics

Several household characteristics may also have an impact on a household's likelihood to engage in searching. Data on household characteristics (zip code level) are gathered from Axciom and include the share of households with the head of the household below the age of 40, the shares of households that moved out (moved households) and into the zip code area (new households), respectively, as well as the share of households with low financial resources (low income). These factors potentially affect consumer search: younger people are more familiar with the internet and therefore have potentially lower search costs, people that move out of a zip code may not be very interested in entering into a new electricity contract in this zip code, new arrivals in a zip code may look for a good electricity tariff there and people with financial constraints may be more likely to search for a cheaper electricity tariff. The summary statistics are shown in Table 1 below. 
Table 1: Summary statistics

\begin{tabular}{|c|c|c|c|c|c|}
\hline & Mean & S.D. & Min & Max & \#Obs. \\
\hline \multicolumn{6}{|l|}{ Information } \\
\hline$\%$ of searching households $(\mu)$ & 9.28 & 6.46 & 0.00 & 36.06 & 30.681 \\
\hline$\Delta \mu$ & 0.54 & 9.44 & -29.67 & 36.37 & 21,128 \\
\hline \multicolumn{6}{|c|}{ Price for $3,500 \mathrm{~kW}$ electricity consumption/year } \\
\hline Price incumbent $(€ / a)$ & 1003.90 & 78.23 & 761.01 & 1204.15 & 30,681 \\
\hline$\Delta$ Price incumbent & 51.58 & 47.57 & -76.10 & 186.41 & 21,128 \\
\hline Price entrant $(€ / a)$ & 807.75 & 58.74 & 657.19 & 903.03 & 30,968 \\
\hline$\Delta$ Price entrant & 43.08 & 34.44 & -85.18 & 153.46 & 21,128 \\
\hline \multicolumn{6}{|c|}{ Computed yearly costs for $3,500 \mathrm{~kW}$ electricity } \\
\hline Costs incumbent & 840.80 & 58.17 & 635.41 & 1021.23 & 30,681 \\
\hline$\Delta$ Costs incumbent & 29.40 & 35.55 & -88.40 & 143.99 & 21,128 \\
\hline Costs cntrant & 809.64 & 56.43 & 658.72 & 989.68 & 30,681 \\
\hline$\Delta$ Costs cntrant & 31.13 & 44.34 & -87.27 & 160.46 & 21,128 \\
\hline Locally varying costs & 254.00 & 31.59 & 103.68 & 384.66 & 30,681 \\
\hline$\Delta$ Locally varying costs & 8.00 & 16.44 & -98.22 & 148.53 & 21,128 \\
\hline \multicolumn{6}{|l|}{ Controls and Instruments } \\
\hline$\%$ Head of household under the age of 40 & 24.60 & 5.00 & 7.70 & 55.00 & 30,968 \\
\hline$\%$ New households & 5.60 & 2.10 & 0.70 & 79.00 & 30,968 \\
\hline$\%$ Moved households & 5.50 & 2.00 & 1.20 & 79.50 & 30,968 \\
\hline$\%$ Low Status & 19,77 & 23,33 & 0 & 100 & 30,968 \\
\hline
\end{tabular}

Note: Summary statistics reported for the period from 2011 to 2014.

A deeper descriptive inspection of the data already suggests that costs are passed through asymmetrically: while costs increased in 16,670 and decreased in 4,458 cases, the incumbents increased prices in 16,779 but decreased them in only 532 occasions. In 3,817 cases the incumbent did not adjust prices. By contrast, the entrants were four times more likely to decrease prices (2,152 cases). 


\section{Consumer Search}

In this section I explore whether consumers' search intensity is a function of prices and price changes, respectively. Figure 1 illustrates the patterns of consumer search on online price comparison sites using click data from the above mentioned online price comparison sites (upper panel) as well as Google Trends for the biggest platform Verivox (lower panel) over time. The red lines document the yearly announcement of next year's Renewable Energy Act (Erneuerbare Energien Gesetz, EEG) cost apportionment. $^{12}$ Due to the increased share of renewables the EEG cost apportionment increased each year in our observation period. Each year the next year's EEG cost apportionment is published on October 15th accompanied by extensive media reporting on the EEG cost apportionment and in particular its increase. Thus, households receive information on an increase of one component of their electricity bill. As households are generally much less aware of the remaining cost components' developments (e.g local grid charges, spot prices etc.), they build their expectations on future retail price developments largely on the EEG cost apportionment which they expect to translate into a price increase the next period. This apparently incentivizes search efforts as search intensity is always highest at the

12 The Renewable Energies Act (EEG) is a promotion tool for renewable energy technologies which equips producers of renewable energies with a 20-year fixed feed-in tariff and unlimited priority feed-in into the grid. In other words, maximum possible generation from renewables will be produced regardless of actual demand and the fixed feed-in tariff is paid instead of a market-based spot price. While the producers of renewable energy receive the fixed feed-id tariff, the system operators are responsible to sell all the produced renewables at the spot market. A result of this process is the EEG cost apportionment which is adjusted yearly. It is primarily calculated as the forecasted yearly difference between the expected expenditures from the fixed feed-in-tariff payments and the expected revenues from selling renewables at the spot market (e.g. forecasted revenues from renewables in 2013 were 3.1 billion Euro and forecasted expenditures were 22.9 billion Euro) plus the error from the last year's calculation. These costs build the basis of the EEG cost apportionment. Based on this forecasted costs a price per $\mathrm{kWh}$ is computed which has to be paid by the households as a component of the retail price - the EEG cost apportionment. Industry is essentially exempted from the EEG cost apportionment. 
time the next year's EEG apportionment is announced. Thus, the figure below provides a first descriptive indication for a relation between price changes and consumer search efforts as it reveals that consumers already search more when they only expect prices to increase.

\section{Figure 1: Development of search queries}
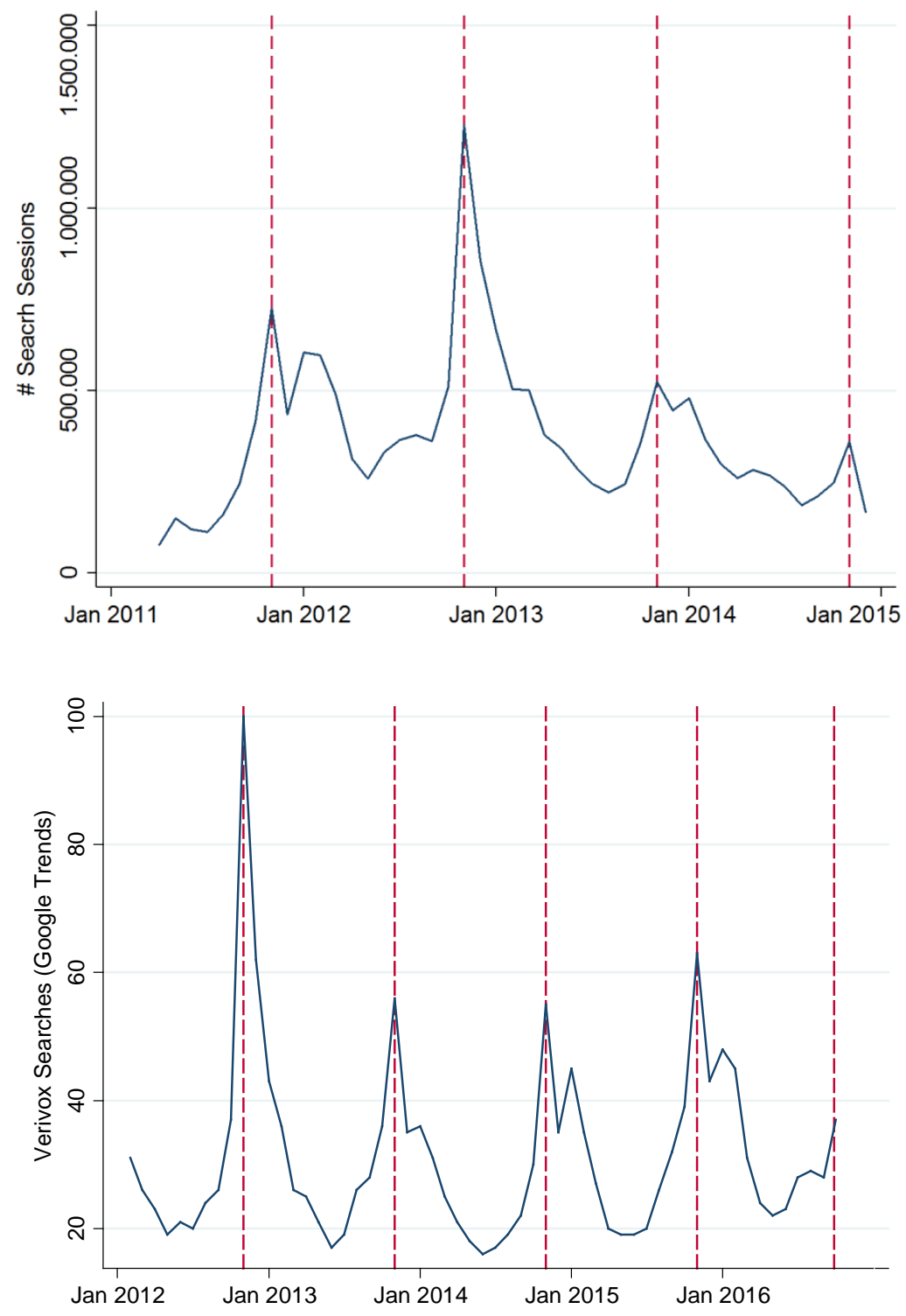

Note: Upper panel: Blue line is aggregated number of search sessions on several online price comparison sites based on click data. Lower panel: Blue line is the search activity on the biggest online price comparison platform Verivox from Google Trends (base month = November 2012). In both figures the red line illustrates the announcement of the next year's EEG cost apportionment. 
While the descriptive illustration shows on aggregate that expected price increases incentivize search efforts, I now estimate the impact of positive and negative price changes on consumer search intensity using panel data. The following model serves as the baseline model:

$$
\Delta \mu_{i t}=\tau_{1}\left(\Delta P_{i t} \times \zeta_{i t}\right)+\rho_{1}\left(\Delta P_{i t} \times\left(1-\zeta_{i t}\right)\right)+X_{i t} \theta_{1}+\gamma_{t 1}+\vartheta_{i 1}+\varepsilon_{1, i t}
$$

The dependent variable $\Delta \mu$ denotes the change in consumer search intensity. $P$ is the electricity price and $\Delta P$ its first difference. $\Delta X$ is a vector of covariates that potentially also effect search activity containing the share of households with the head of the household being below the age of 40, the share of moved and new households as well as the share of households with low financial resources. Subscripts $i$ and $t$ index zip codes and years, respectively. $\zeta$ is a sign operator which is equal to one if the price has increased compared to the last period and zero otherwise. Thus, $\Delta P \times \zeta$ represents the change in the electricity bill when it has increased and $\Delta P \times(1-\zeta)$ when it has decreased.

To consider a potential reverse causality between consumer search efforts and pricing I apply instrumental variable techniques and instrument for $\Delta P \times \zeta$ and $\Delta P \times(1-\zeta)$. The instruments are $\Delta C^{v} \times \eta$ and $\Delta C^{v} \times(1-\eta)$ where $C^{v}$ reflects the regionally varying costs associated with $P . \eta$ is the sign operator for cost changes. Thus, the two endogenous variables $\Delta P \times \zeta$ and $\Delta P \times(1-\zeta)$ are exactly identified by the instruments. The two first stages are estimated as below:

$$
\Delta P_{i t} \times \zeta_{i t}=\alpha_{1}\left(\Delta C_{i t}^{v} \times \eta_{i t}\right)+\beta_{1}\left(\Delta C_{i t}^{v} \times\left(1-\eta_{i t}\right)\right)+X_{i t} \theta_{2}+\gamma_{t 2}+\vartheta_{i 2}+\varepsilon_{2, i t}
$$

and

$$
\Delta P_{i t} \times\left(1-\zeta_{i t}\right)=\alpha_{2}\left(\Delta C_{i t}^{v} \times \eta_{i t}\right)+\beta_{2}\left(\Delta C_{i t}^{v} \times\left(1-\eta_{i t}\right)\right)+X_{i t} \theta_{3}+\gamma_{t 3}+\vartheta_{i 3}+\varepsilon_{3, i t}
$$


The IV estimates of equation 1 are reported in column 5 of Table 2. Columns 1 to 4 of the same table contain alternative estimations of the impact of prices and price changes, respectively, on consumer search efforts. The dependent variable in columns 1 to 3 is the level of consumer search intensity and in columns 4 and 5 the dependent variable is the yearly change in consumer search intensity, i.e. the first difference of consumer search intensity. The Kleibergen-Paap statistic indicates that the endogenous variables are identified by the instruments in all models as the critical values by Stock and Yogo are always exceeded. ${ }^{13}$

In column 1 I estimate the impact of price on search intensity using a linear specification for price. The locally varying costs are used to instrument for price. It can be seen that consumers search significantly more when prices are high which is in line with theory. However, the impact is non-linear as suggested by the estimates in column 2 which also includes the squared price (instrumented by the squared variable costs). Both, the price level and its square are significant. The extreme point of the price function is at 655 Euro which is below the minimum of 761 Euro (range 761 to 1204, see also Table 1. Thus, the impact of price on search is strictly convex increasing.

The model in column 3 is identical with the baseline model from equation 1 (reported in column 5) with the only difference that the dependent variable is the level of search intensity $\mu$ instead of its first difference $\Delta \mu$. As the results are qualitatively similar I will focus on the interpretation of the estimates in column 5, which suggest that rising prices induce significant increases in consumer search intensity and falling prices cause significant reductions in search efforts. However, the impact of price decreases on the

\footnotetext{
${ }^{13}$ The Kleibergen-Paap rk Wald F-statistic is the multivariate analogue of the first stage F-test. In the case of a single endogenous variable the Kleibergen-Paap statistic is identical to the first stage Fstatistic.
} 
adjustment of consumer search efforts is substantially higher: consumers reduce their search efforts much more when prices fall (coefficient 0.0111) then they increase search efforts when prices rise (coefficient 0.0006). ${ }^{14}$ If the electricity bill has increased by 10 Euro from the last period search intensity increases by approximately $0.6 \%$. However, when price has decreased by 10 Euro then search intensity is reduced by almost $11 \% .{ }^{15}$ Not surprisingly, this huge difference is statistically significant as a t-test rejects the null hypothesis of equality of $\tau$ and $\rho$ thereby indicating an asymmetric adjustment of consumer search efforts to positive and negative price shocks. Thus, if search intensity affects cost pass-through then the asymmetry in the adjustment of search efforts with regard to price changes would even increase the asymmetry in cost pass-through if one would not control for search intensity.

\footnotetext{
14 Note that price increases always have a positive sign while price decreases are negative. Thus, a positive sign for the coefficient of a price decrease has to be interpreted in the sense, that falling prices cause consumers to reduce search efforts.

15 These values should help to illustrate the asymmetric adjustment of search efforts with respect to positive and negative price changes. However, as I only observe search queries on some of the price comparison sites (not on all) they should not be interpreted as the real absolute effect of price on search but rather as the impact of price on the search efforts on the observed price comparison sites.
} 
Table 2: IV estimates of search intensity

\begin{tabular}{|c|c|c|c|c|c|}
\hline Dependent Variable is & $\begin{array}{c}\mathrm{IV} 1 \\
\mu\end{array}$ & $\begin{array}{c}\mathrm{IV} 2 \\
\mu\end{array}$ & $\begin{array}{c}\mathrm{IV} 3 \\
\mu\end{array}$ & $\begin{array}{c}\mathrm{IV} 4 \\
\Delta \mu\end{array}$ & $\begin{array}{l}\mathrm{IV} 5 \\
\Delta \mu\end{array}$ \\
\hline$P$ & $\begin{array}{l}0.0007^{* * *} \\
(0.0000)\end{array}$ & $\begin{array}{c}-0.0012^{* * *} \\
(0.0003)\end{array}$ & & & \\
\hline$P^{2}$ & & $\begin{array}{c}9.37 \mathrm{e}-07^{* * *} \\
(0.0000)\end{array}$ & & & \\
\hline$\Delta P \times \zeta$ & & & $\begin{array}{l}0.0003^{* * *} \\
(0.0000)\end{array}$ & & $\begin{array}{c}0.0006^{* * *} \\
(0.0001)\end{array}$ \\
\hline$\Delta P \times(1-\zeta)$ & & & $\begin{array}{l}0.0163^{* * *} \\
(0.0042)\end{array}$ & & $\begin{array}{c}0.0111^{* * *} \\
(0.0039)\end{array}$ \\
\hline$\Delta P$ & & & & $\begin{array}{l}0.0007^{* * *} \\
(0.0001)\end{array}$ & \\
\hline share $\mathrm{HH}$ under age of 40 & $\begin{array}{l}0.0845^{* * *} \\
(0.0270)\end{array}$ & $\begin{array}{l}0.1257^{* * *} \\
(0.0280)\end{array}$ & $\begin{array}{c}0.3183^{* * *} \\
(0.0692)\end{array}$ & $\begin{array}{l}0.4244^{* * *} \\
(0.0693)\end{array}$ & $\begin{array}{c}0.3383^{* * *} \\
(0.0830)\end{array}$ \\
\hline share moved HH & $\begin{array}{l}0.1602^{* * *} \\
(0.0426)\end{array}$ & $\begin{array}{l}0.1577^{* * *} \\
(0.0427)\end{array}$ & $\begin{array}{c}0.0858 \\
(0.0696)\end{array}$ & $\begin{array}{l}-0.0309 \\
(0.0864)\end{array}$ & $\begin{array}{l}-0.0030 \\
(0.0929)\end{array}$ \\
\hline share new HH & $\begin{array}{c}-0.1006^{* *} \\
(0.0415)\end{array}$ & $\begin{array}{l}-0.0772^{*} \\
(0.0418)\end{array}$ & $\begin{array}{c}-0.0151 \\
(0.0665)\end{array}$ & $\begin{array}{c}0.0501 \\
(0.0857)\end{array}$ & $\begin{array}{c}0.0549 \\
(0.0897)\end{array}$ \\
\hline share HH with low income & $\begin{array}{c}0.0021 \\
(0.0021)\end{array}$ & $\begin{array}{c}0.0008 \\
(0.0021)\end{array}$ & $\begin{array}{l}0.0089^{* *} \\
(0.0044)\end{array}$ & $\begin{array}{c}0.0025 \\
(0.0048)\end{array}$ & $\begin{array}{c}0.0097^{*} \\
(0.0055)\end{array}$ \\
\hline Year Fixed Effects & Yes & Yes & Yes & Yes & Yes \\
\hline Zip Code Fixed Effects & Yes & Yes & Yes & Yes & Yes \\
\hline$\tau=\rho$ (p-val. $)$ & - & - & 0.00 & - & 0.01 \\
\hline $\begin{array}{l}\text { U-Shape Test Extreme Values } \\
\text { (Range) }\end{array}$ & - & $\begin{array}{c}655 \\
(761-1204)\end{array}$ & - & - & - \\
\hline Kleibergen-Paap $F$ statistic & 1115.29 & 494.70 & 11.84 & 1557.43 & 11.84 \\
\hline $\begin{array}{l}\text { Critical Stock and Yogo } 10 \% \\
\text { value for KP stat. }\end{array}$ & 16.38 & 7.03 & 7.03 & 16.38 & 7.03 \\
\hline $\begin{array}{l}\text { Durbin-Wu-Hausman Test (p- } \\
\text { val.) }\end{array}$ & 0.00 & 0.00 & 0.00 & 0.00 & 0.00 \\
\hline \# Obs. & 30951 & 30951 & 21128 & 21128 & 21128 \\
\hline
\end{tabular}

Note: Cluster-robust standard errors in parenthesis (clustered on zip codes). All models include zip code area and year fixed effects. Estimation is by Continuously Updating Efficient GMM (CUE). Instruments for the price variables are: $C^{v}$ for $P$, squared $C^{v}$ for $P^{2}, \Delta C^{v}$ for $\Delta P$, $\Delta C^{v} \times \eta$ for $\Delta P \times \zeta$ and $\Delta C^{v} \times(1-\eta)$ for $\Delta P \times(1-\zeta)$. 


\section{Cost Pass-Through}

In the next step I first investigate whether the standard approach in detecting asymmetric pass-through rates generates asymmetric results for my data by estimating the below model for the incumbents.

$$
\Delta P_{i t}=\tau_{2}\left(\Delta C_{t i} \times \eta\right)+\rho_{2}\left(\Delta C_{t i} \times(1-\eta)+\gamma_{t 4}+\vartheta_{i 4}+\varepsilon_{4, i t}\right.
$$

The notation is as above. $\tau_{2}>\rho_{2}$ would indicate that costs are passed-through asymmetrically and this is what the estimates in Table 3 suggest.

Subsequently, I additionally include consumer search intensity $(\mu)$ as a control variable and re-estimate equation 4 . If search contributes to price adjustments in the assumed way than its coefficient should be significantly negative: more search causes a lower pass-through rate. If costs rise than prices increase less when search intensity is high and analogously if costs fall price decreases are higher in absolute terms (more negative) if search intensity is high. ${ }^{16}$ Technically, the equation I estimate is:

$$
\Delta P_{i t}=\tau_{3}\left(\Delta C_{t i} \times \eta\right)+\rho_{3}\left(\Delta C_{t i} \times(1-\eta)\right)+\varphi \mu++\gamma_{t 5}+\vartheta_{i 5}+\varepsilon_{5, i t}
$$

As already discussed search activity is likely endogenous to price due to simultaneous effects and therefore I instrument for $\mu$. The instruments for $\mu$ are the share of households below the age of 40, the share of moved households, the share of new households and - in order to capture asymmetry in the search behaviour with regard to price changes - also include interactions of the three instruments with cost increases $(\Delta C \times \eta)$ as well as with cost decreases $(\Delta C \times(1-\eta)) \cdot{ }^{17}$

\footnotetext{
${ }^{16}$ Again, note that price decreases have negative signs. Thus, the value of a price decrease is lower the more the price is decreased.

${ }^{17}$ I do not include the share of households with low income into the list of instruments. The reason is that low incomes may increase the risk of non-payment. Retailers potentially reflect this risk in their prices. Therefore, I include the share of households with low income into the model as a control variable.
} 
Thus, the first stage is as below:

$$
\mu_{i t}=\tau_{4}\left(\Delta C_{t i} \times \eta\right)+\rho_{4}\left(\Delta C_{t i} \times(1-\eta)\right)+Z_{i t} \theta_{4}+\gamma_{t 6}+\vartheta_{i 6}+\varepsilon_{6, i t}
$$

$Z$ is a set of instruments containing the nine above discussed instruments. The remaining notation is as before.

The estimates of equation 4 are reported in columns 1 and 2 of Table 3 . The difference between the estimations in column 1 and column 2 is that I also control for the number of competitors that are active in the respective zip code-year pair which provides an additional measure of competition in the local market. As entry is cheap and easy in the market I use the number of competitors lagged by one year to avoid problems with endogeneity. Turning to the cost pass-through rates the estimates suggest that costs are passed through asymmetrically. $\tau_{2}$ is 0.74 and $\rho_{2}$ is $0.41-$ a cost increase of 1 Euro causes an average price increase of 0.74 Euro while a cost decrease of 1 Euro only causes a 0.41 Euro price reduction. The null hypothesis that positive and negative cost shocks are passed-through symmetrically is clearly rejected by a ttest. Interestingly, the estimated pass-through rate is pretty much in line with Peltzman (2000) who finds that on average, the immediate response to a positive price shock is at approximately twice as high the response to a negative cost shock (1.8 times higher here).

In the next step, I estimate equation 5 which basically adds consumer search intensity $\mu$ to equation 4 . The results of these estimations are reported in columns 3 and 4 where column 4 additionally contains the number of competitors. Consumer search intensity is highly significant and indeed, adding consumer search intensity $\mu$ substantially changes the results and particularly eliminates the asymmetric pass-

However, the results do not change if the share of households with low income is included as an additional instrument. 
through rate. The cost pass-through rates are now is 0.83 and 0.86 Euro. Thus, a cost increase of 1 Euro is followed by a 1 Euro price increase and a cost decrease of 1 Euro causes a price reduction as high as 0.86 Euro. A t-test cannot reject the null hypotheses of equal coefficients $\tau_{2}$ and $\rho_{2}$ anymore.

In columns 5 and $6 \mathrm{I}$ replace $\mu$ with its first difference $\Delta \mu$ in order to test for the impact of changes in consumer search intensity on price adjustments. ${ }^{18}$ Again, the coefficient is significant and negative suggesting that changes in consumer search intensity decrease pass-through, i.e. if consumers increase their search efforts prices are increased less when costs rise and are decreased more when costs fall. The more consumers are informed the closer we get to the Bertrand equilibrium. The same is valid for the number of competitors which also comes up with a statistically significant negative sign.

\footnotetext{
${ }^{18}$ I employ the same set of instruments as for $\mu$.
} 
Table 3: Impact of cost changes on price adjustments (incumbents)

\begin{tabular}{|c|c|c|c|c|c|c|}
\hline Dependent variable is $\Delta P$ & (1) & (2) & (3) & (4) & (5) & (6) \\
\hline & OLS & OLS & IV & IV & IV & IV \\
\hline$\Delta C \times \eta$ & $\begin{array}{l}0.76^{* * *} \\
(39.87)\end{array}$ & $\begin{array}{l}0.74^{* * *} \\
(38.89)\end{array}$ & $\begin{array}{l}0.85^{* * *} \\
(35.01)\end{array}$ & $\begin{array}{l}0.83^{* * *} \\
(33.64)\end{array}$ & $\begin{array}{l}0.80^{* * *} \\
(38.46)\end{array}$ & $\begin{array}{l}0.78^{* * *} \\
(37.69)\end{array}$ \\
\hline$\Delta C \times(1-\eta)$ & $\begin{array}{l}0.50^{* * *} \\
(19.23)\end{array}$ & $\begin{array}{l}0.41^{* * *} \\
(14.93)\end{array}$ & $\begin{array}{l}0.97^{* * *} \\
(18.01)\end{array}$ & $\begin{array}{l}0.86^{* * *} \\
(15.71)\end{array}$ & $\begin{array}{l}0.77^{* * *} \\
(20.59)\end{array}$ & $\begin{array}{l}0.64^{* * *} \\
(17.30)\end{array}$ \\
\hline$\mu$ & & & $\begin{array}{c}-484.54^{* * *} \\
(-12.46)\end{array}$ & $\begin{array}{c}-565.43^{* * *} \\
(-13.09)\end{array}$ & & \\
\hline$\Delta \mu$ & & & & & $\begin{array}{c}-146.66^{* * *} \\
(-12.01)\end{array}$ & $\begin{array}{c}-154.39^{* * *} \\
(-12.21)\end{array}$ \\
\hline Share of $\mathrm{HH}$ with low income & $\begin{array}{l}2.54^{* * *} \\
(2.75)\end{array}$ & $\begin{array}{l}2.55^{* * *} \\
(2.77)\end{array}$ & $\begin{array}{c}1.51 \\
(0.88)\end{array}$ & $\begin{array}{c}1.74 \\
(0.90)\end{array}$ & $\begin{array}{l}2.68^{* *} \\
(2.27)\end{array}$ & $\begin{array}{l}2.94^{* *} \\
(2.46)\end{array}$ \\
\hline Lagged \#Competitors & & $\begin{array}{l}-0.44^{* * *} \\
(-10.18)\end{array}$ & & $\begin{array}{l}-1.01^{* * *} \\
(-12.13)\end{array}$ & & $\begin{array}{l}-0.79^{* * *} \\
(-13.59)\end{array}$ \\
\hline Zip code FE & Yes & Yes & Yes & Yes & Yes & Yes \\
\hline Year FE & Yes & Yes & Yes & Yes & Yes & Yes \\
\hline$\tau=\rho$ (p-val.) & 0.00 & 0.00 & 0.05 & 0.59 & 0.56 & 0.00 \\
\hline Kleibergen-Paap $F$ statistic & - & - & 31.10 & 28.91 & 62.17 & 59.40 \\
\hline Critical Stock-Yogo $10 \%$ value & - & - & 3.58 & 3.58 & 3.58 & 3.58 \\
\hline Wu-Hausman Test (p-val.) & - & - & 0.00 & 0.16 & 0.00 & 0.00 \\
\hline \# Obs. & 21128 & 21128 & 21128 & 21128 & 21128 & 21128 \\
\hline
\end{tabular}

Note: Cluster-robust standard errors in parenthesis. All models include zip code area and year fixed effects. Estimation is by Continuously Updating GMM (CUE). $\mu$ and $\Delta \mu$, respectively, are endogenous. Instruments are the share of $\mathrm{HH}$ under the age of 40, the share of new households and the share of moved households as well as the interactions of these three variables with cost increases $(\Delta C \times \eta)$ and decreases $(\Delta C \times(1-\eta))$.

\section{Counterfactual}

As mentioned before I also observe an interesting counterfactual. The entrants' situation substantially differs from the incumbents' situation as initially all consumers are automatically assigned to the incumbents' standard tariffs. In other words, switching to an entrant requires active searching by a household. For this reason the entrants' consumers are fully informed (at least if they search via a price comparison site). Thus, the impact of consumer search intensity on price adjustments should be much lower for the entrants. 
To test this I now estimate models 4 and 5 for the price adjustments of the cheapest entrants. The hypothesis in this case is that there should not be an effect on cost passthrough when controlling for consumer search as all potential consumers of the entrants are already fully informed and know the tariffs. Thus, search intensity does not substantially change the entrants' elasticity of demand. This is actually what the estimates suggest and the models which control for search intensity and those who do not only differ marginally as shown in Table 4. However, somehow surprisingly the estimates suggest that there is still an asymmetric cost pass-through but with the opposite direction: negative cost shocks are passed-through to a higher degree than positive cost shocks which one could call 'stones and balloons' or 'negative asymmetry' as termed by Peltzman (2000). A potential explanation is that entrants generally provide a first-year bonus for new consumers which is include in the prices I observe for the entrants. It is possible that the entrants try to capture those consumers with search costs, i.e. those consumers that only search when prices increase, by giving them a high first-year bonus. 
Table 4: Impact of cost changes on price adjustments (cheapest entrants)

\begin{tabular}{|c|c|c|c|c|c|c|}
\hline Dependent variable is $\Delta P$ & $(1)$ & $(2)$ & $(3)$ & $(4)$ & $(5)$ & $(6)$ \\
\hline$\Delta C \times \eta$ & $\begin{array}{c}0.66^{* * *} \\
(43.56)\end{array}$ & $\begin{array}{c}0.64^{* * *} \\
(42.53)\end{array}$ & $\begin{array}{l}0.61^{* * *} \\
(38.84)\end{array}$ & $\begin{array}{l}0.61^{* * *} \\
(38.60)\end{array}$ & $\begin{array}{c}0.63^{* * *} \\
(41.74)\end{array}$ & $\begin{array}{l}0.62^{\text {*** }} \\
(41.38)\end{array}$ \\
\hline$\Delta C \times(1-\eta)$ & $\begin{array}{l}0.87^{* * *} \\
(38.58)\end{array}$ & $\begin{array}{c}0.79^{* * *} \\
(33.00)\end{array}$ & $\begin{array}{l}0.83^{* * *} \\
(36.94)\end{array}$ & $\begin{array}{l}0.78^{* * *} \\
(34.84)\end{array}$ & $\begin{array}{c}0.86^{* * *} \\
(43.66)\end{array}$ & $\begin{array}{l}0.83^{\text {*** }} \\
(41.29)\end{array}$ \\
\hline$\mu$ & & & $\begin{array}{c}176.11^{* * *} \\
(7.88)\end{array}$ & $\begin{array}{c}187.01^{* * *} \\
(8.20)\end{array}$ & & \\
\hline$\Delta \mu$ & & & & & $\begin{array}{c}74.29^{* * *} \\
(8.21)\end{array}$ & $\begin{array}{c}75.63^{* * *} \\
(8.23)\end{array}$ \\
\hline Share of $\mathrm{HH}$ with low income & $\begin{array}{l}-2.99^{* * *} \\
(-3.32)\end{array}$ & $\begin{array}{l}-2.96^{* * *} \\
(-3.20)\end{array}$ & $\begin{array}{l}-2.82^{* * *} \\
(-2.94)\end{array}$ & $\begin{array}{l}-2.87^{* * *} \\
(-2.94)\end{array}$ & $\begin{array}{l}-3.40^{* * *} \\
(-3.72)\end{array}$ & $\begin{array}{c}-3.44^{* * *} \\
(-3.73)\end{array}$ \\
\hline Lagged \#Competitors & & $\begin{array}{l}-0.43^{* * *} \\
(-11.79)\end{array}$ & & $\begin{array}{l}-0.17^{* * *} \\
(-3.86)\end{array}$ & & $\begin{array}{l}-0.18^{* * *} \\
(-4.25)\end{array}$ \\
\hline Zip code FE & $\begin{array}{l}\text { Yes } \\
\text { Yes }\end{array}$ & $\begin{array}{l}\text { Yes } \\
\text { Yes }\end{array}$ & $\begin{array}{l}\text { Yes } \\
\text { Yes }\end{array}$ & $\begin{array}{l}\text { Yes } \\
\text { Yes }\end{array}$ & $\begin{array}{l}\text { Yes } \\
\text { Yes }\end{array}$ & $\begin{array}{l}\text { Yes } \\
\text { Yes }\end{array}$ \\
\hline$\tau=\rho$ (p-val. $)$ & 0.00 & 0.00 & 0.00 & 0.00 & 0.00 & 0.00 \\
\hline Kleibergen-Paap $F$ statistic & - & - & 31.86 & 30.13 & 63.36 & 61.71 \\
\hline Critical Stock-Yogo $10 \%$ value & - & - & 3.58 & 3.58 & 3.58 & 3.58 \\
\hline Wu-Hausman Test (p-val.) & - & - & 0.00 & 0.16 & 0.00 & 0.00 \\
\hline \# Obs. & 21128 & 21128 & 21128 & 21128 & 21128 & 21128 \\
\hline
\end{tabular}

Note: Cluster-robust standard errors in parenthesis. All models include zip code area and year fixed effects. Estimation is by Continuously Updating GMM (CUE). $\mu$ and $\Delta \mu$, respectively, are endogenous. Instruments are the share of $\mathrm{HH}$ under the age of 40, the share of new households and the share of moved households as well as the interactions of these three variables with cost increases $(\Delta C \times \eta)$ and decreases $(\Delta C \times(1-\eta))$.

Cost Changes, Lerner-Index and Search

As an alternative specification I now estimate the impact of cost adjustments on the Lerner-Index. As I have information on both, cost components and prices the Lerner Index can be computed easily and is $L I_{i t}=\frac{P_{i t}-C_{i t}}{P_{i t}}$.

Employing the Lerner-Index as dependent variable has the advantage that it accounts for the price-cost ratio, i.e. I estimate the impact of positive and negative cost shocks on margin squeeze. The results are reported in Table 5 below. Again it can be seen 
that search intensity drives the results and the coefficient for search intensity is always significant and negative suggesting that search intensity reduces market power. Also, in models where I do not control for search intensity I find that a 1 Euro cost decrease causes a Lerner Index increase of 0.00059 while a 1 Euro cost increase reduces the Lerner Index by around 0.00036 (column 2). However, when search intensity is included into the impact of a 1 Euro cost decrease on the Lerner-Index is approximately two-thirds lower (0.00021) as can be seen from column 4. By contrast, including search intensity decreases the impact of cost increases on the Lerner-Index, though only slightly, from 0.00036 to 0.00030 (comparison of columns 2 and 4).

The results again suggest that search intensity is an important driver of market outcomes. High search intensity significantly reduces market power as measured by the Lerner-Index.

Table 5: Impact of cost changes on Lerner Index (incumbents)

\begin{tabular}{|c|c|c|c|c|c|c|}
\hline \multirow[t]{2}{*}{ Dependent variable is $\Delta L I$} & $(1)$ & $(2)$ & (3) & (4) & (5) & (6) \\
\hline & OLS & OLS & IV & IV & IV & IV \\
\hline$\Delta C \times \eta$ & $\begin{array}{c}-0.00034^{* * *} \\
(-20.54)\end{array}$ & $\begin{array}{c}-0.00036^{* * *} \\
(-21.30)\end{array}$ & $\begin{array}{c}-0.00028^{* * *} \\
(-13.39)\end{array}$ & $\begin{array}{c}-0.00030^{* * *} \\
(-14.39)\end{array}$ & $\begin{array}{c}-0.00032^{* * *} \\
(-18.08)\end{array}$ & $\begin{array}{c}-0.00034^{* * *} \\
(-19.29)\end{array}$ \\
\hline$\Delta C \times(1-\eta)$ & $\begin{array}{c}-0.00052^{* * *} \\
(-22.15)\end{array}$ & $\begin{array}{c}-0.00059^{* * *} \\
(-23.83)\end{array}$ & $\begin{array}{c}-0.00010^{* *} \\
(-2.22)\end{array}$ & $\begin{array}{c}-0.00021^{* * *} \\
(-4.39)\end{array}$ & $\begin{array}{c}-0.00025^{* * *} \\
(-7.59)\end{array}$ & $\begin{array}{c}-0.00036^{* * *} \\
(-11.00)\end{array}$ \\
\hline$\mu$ & & & $\begin{array}{l}-0.39^{* * *} \\
(-12.01)\end{array}$ & $\begin{array}{l}-0.44^{* * *} \\
(-12.54)\end{array}$ & & \\
\hline$\Delta \mu$ & & & & & $\begin{array}{l}-0.12^{* * *} \\
(-11.57)\end{array}$ & $\begin{array}{l}-0.13^{* * *} \\
(-11.73)\end{array}$ \\
\hline Share of $\mathrm{HH}$ with low income & $\begin{array}{c}0.003^{* * *} \\
(3.47)\end{array}$ & $\begin{array}{c}0.003^{* * *} \\
(3.51)\end{array}$ & $\begin{array}{l}0.002 \\
(1.34)\end{array}$ & $\begin{array}{l}0.002 \\
(1.27)\end{array}$ & $\begin{array}{c}0.003^{* * *} \\
(2.84)\end{array}$ & $\begin{array}{c}0.003^{* * *} \\
(2.96)\end{array}$ \\
\hline Lagged \#Competitors & & $\begin{array}{c}-0.0004^{* * *} \\
(-10.61)\end{array}$ & & $\begin{array}{c}-0.0008^{* * *} \\
(-12.32)\end{array}$ & & $\begin{array}{c}-0.0007^{* * *} \\
(-13.65)\end{array}$ \\
\hline Zip code FE & Yes & Yes & Yes & Yes & Yes & Yes \\
\hline Year FE & Yes & Yes & Yes & Yes & Yes & Yes \\
\hline$\tau=\rho$ (p-val.) & 0.00 & 0.00 & 0.00 & 0.08 & 0.10 & 0.62 \\
\hline Kleibergen-Paap $F$ statistic & - & - & 28.90 & 26.98 & 57.92 & 55.60 \\
\hline Critical Stock-Yogo 10\% val. & - & - & 3.58 & 3.58 & 3.58 & 3.58 \\
\hline Wu-Hausman Test (p-val.) & - & - & 0.02 & 0.33 & 0.00 & 0.00 \\
\hline \# Obs. & 21128 & 21128 & 21128 & 21128 & 21128 & 21128 \\
\hline
\end{tabular}


Note: Cluster-robust standard errors in parenthesis. All models include zip code area and year fixed effects. Estimation is by Continuously Updating GMM (CUE). $\mu$ and $\Delta \mu$, respectively, are endogenous. Instruments are the share of $\mathrm{HH}$ under the age of 40, the share of new households and the share of moved households as well as the interactions of these three variables with cost increases $(\Delta C \times \eta)$ and decreases $(\Delta C \times(1-\eta))$.

As before, I also estimate the same models for the incumbent. Again, the impact of search intensity is expected to be substantially lower than for the incumbents and again, the estimates confirm this hypothesis as shown in Table 6 .

Table 6: Impact of cost changes on Lerner Index (cheapest entrants)

\begin{tabular}{|c|c|c|c|c|c|c|}
\hline Dependent variable is $\Delta L I$ & $\begin{array}{l}(1) \\
\text { OLS }\end{array}$ & $\begin{array}{c}(2) \\
\text { OLS }\end{array}$ & $\begin{array}{l}(3) \\
\text { IV }\end{array}$ & $\begin{array}{l}(4) \\
\text { IV }\end{array}$ & $\begin{array}{l}(5) \\
\text { IV }\end{array}$ & $\begin{array}{l}(6) \\
\text { IV }\end{array}$ \\
\hline$\Delta C \times \eta$ & $\begin{array}{c}-0.00040^{* * *} \\
(-21.02)\end{array}$ & $\begin{array}{c}-0.00042^{* * *} \\
(-22.05)\end{array}$ & $\begin{array}{c}-0.00045^{* * *} \\
(-23.00)\end{array}$ & $\begin{array}{c}-0.00046^{* * *} \\
(-23.63)\end{array}$ & $\begin{array}{c}-0.00043^{* * *} \\
(-23.15)\end{array}$ & $\begin{array}{c}-0.00044^{* * *} \\
(-23.63)\end{array}$ \\
\hline$\Delta C \times(1-\eta)$ & $\begin{array}{c}-0.00016^{* * *} \\
(-5.69)\end{array}$ & $\begin{array}{c}-0.00026^{* * *} \\
(-8.84)\end{array}$ & $\begin{array}{c}-0.00022^{* * *} \\
(-7.88)\end{array}$ & $\begin{array}{c}-0.00027^{* * *} \\
(-9.92)\end{array}$ & $\begin{array}{c}-0.00018^{* * *} \\
(-7.27)\end{array}$ & $\begin{array}{c}-0.00022^{* * *} \\
(-8.97)\end{array}$ \\
\hline$\mu$ & & & $\begin{array}{l}0.20^{* * *} \\
(7.25)\end{array}$ & $\begin{array}{l}0.21^{* * *} \\
(7.48)\end{array}$ & & \\
\hline$\Delta \mu$ & & & & & $\begin{array}{l}0.08^{* * *} \\
(7.27)\end{array}$ & $\begin{array}{l}0.08^{* * *} \\
(7.28)\end{array}$ \\
\hline Share of $\mathrm{HH}$ with low income & $\begin{array}{c}-0.002^{*} \\
(-1.93)\end{array}$ & $\begin{array}{c}-0.002^{*} \\
(-1.86)\end{array}$ & $\begin{array}{c}-0.002^{*} \\
(-1.70)\end{array}$ & $\begin{array}{c}-0.002^{*} \\
(-1.72)\end{array}$ & $\begin{array}{c}-0.003^{* *} \\
(-2.28)\end{array}$ & $\begin{array}{c}-0.003^{* *} \\
(-2.29)\end{array}$ \\
\hline Lagged \#Competitors & & $\begin{array}{c}-0.0005^{* * *} \\
(-10.89)\end{array}$ & & $\begin{array}{c}-0.0002^{* * *} \\
(-3.95)\end{array}$ & & $\begin{array}{c}-0.0002^{* * *} \\
(-4.47)\end{array}$ \\
\hline Zip code FE & Yes & Yes & Yes & Yes & Yes & Yes \\
\hline Year FE & Yes & Yes & Yes & Yes & Yes & Yes \\
\hline$\tau=\rho$ (p-val. $)$ & 0.00 & 0.00 & 0.00 & 0.00 & 0.00 & 0.00 \\
\hline Kleibergen-Paap $F$ statistic & - & - & 29.62 & 28.12 & 59.10 & 57.79 \\
\hline Critical Stock-Yogo $10 \%$ val. & - & - & 3.58 & 3.58 & 3.58 & 3.58 \\
\hline Wu-Hausman Test (p-val.) & - & - & 0.00 & 0.00 & 0.00 & 0.00 \\
\hline \# Obs. & 21128 & 21128 & 21128 & 21128 & 21128 & 21128 \\
\hline
\end{tabular}

Note: Cluster-robust standard errors in parenthesis. All models include zip code area and year fixed effects. Estimation is by Continuously Updating GMM (CUE). $\mu$ and $\Delta \mu$, respectively, are endogenous. Instruments are the share of $\mathrm{HH}$ under the age of 40, the share of new households and the share of moved households as well as the interactions of these three variables with cost increases $(\Delta C \times \eta)$ and decreases $(\Delta C \times(1-\eta))$. 


\section{Conclusion}

The 'Rocket and Feathers' phenomenon - prices rise more strongly (or quickly) when costs increase than they fall when costs decrease - is often assigned to collusion but observed to the same extent in atomistic markets (Peltzman, 2000). Recent economic theory therefore aims to explain asymmetric cost pass-through by different reactions of consumers' search efforts to positive and negative price adjustments. I empirically investigate this for the German retail electricity market utilizing a unique panel data set on prices, costs and consumer search intensity (i.e. click data from online price comparison sites for electricity tariffs) on zip code level. The market provides several useful properties for this type of analysis: 1) electricity is a homogenous good, 2) There are many local supply areas with different prices and costs in Germany, 3) since the liberalization in 1997 a household in a certain zip code has the freedom to choose between 155 retailers on average, depending on its location, 4) The former incumbents' consumers are largely uninformed and those of the entrants are informed as all households are initially assigned to the incumbent while switching to an entrant requires consumer search efforts and 5) a household's electricity demand is inelastic in the short-term. However, even switching to an entrant would generate substantial savings the vast majority of consumers is still provided by the former incumbent $(78 \%$ in 2014). Thus, if asymmetric cost pass-through is observed for the incumbents then collusion may not be a reasonable explanation but consumer search efforts may be. The entrants serve as a control group as their customers are particularly informed.

The empirical results clearly support theories on a link between search intensity and price adjustments. First, the estimates suggest that consumers' search intensity is a function of prices and price changes, respectively. Second, I find evidence for an asymmetric cost pass-through if I do not control for consumer search intensity. Third, consumer search intensity has a significantly negative impact on price adjustments and 
the asymmetry in cost pass-through for positive and negative costs shocks essentially disappears after controlling for consumer search intensity. For the entrants I do not observe 'Rockets and Feathers' patterns and adding consumer search intensity does not change the results. Thus, the analysis provides empirical evidence for an alternative explanation to collusion for asymmetric cost pass-through. The findings suggest that the frequently observed 'Rockets and Feathers' phenomenon may be explained by an omitting variable bias if the impact of consumer search intensity on price adjustments is neglected. 


\section{References}

A.T. Kearney (2012) Der Strom- und Gasvertrieb im Wandel, Presentation, Berlin. https://www.atkearney.de/documents/856314/1214638/BIP_Der_Strom_und_ Gasvertrieb_im_Wandel.pdf/ee091e7c-9406-4b23-b5b3-608f936cbecc

Bacon, R.W. (1991) Rockets and Feathers: The Asymmetric Speed of Adjustment of UK Retail Gasoline Prices to Cost Changes. Energy Economics, 13(3), pp. 211-218.

Baye, M.R., Morgan, J. and Scholten, P. (2004) Price Dispersion in the Small and in the Large: Evidence from an Internet Price Comparison Site. Journal of Industrial Economics, 52(4), 463-496.

Borenstein, S., Cameron, A.C., and Gilbert, R (1997) Do Gasoline Prices Respond Asymmetrically to Crude Oil Price Changes?. Quarterly Journal of Economics, 112(1), pp. 305-339.

Bundesnetzagentur (Federal Network Agency) and Bundeskartellamt (Federal Cartel Office (2014) Monitoringreport.

Cabral, L. and Fishman, A. (2012) Business as Usual: A Consumer Search Theory of Sticky Prices and Asymmetric Price Adjustment. International Journal of Industrial Organization, 30(4), pp. 371-376

Cabral, L. and Gilbukh, S. (2015) Rational Buyers Search when prices increase. Working Paper, accessible at:

https://editorialexpress.com/cgi-

bin/conference/download.cgi?db_name=IIOC2015\&paper_id $=443$

Chandra, A. and Tappata, M. (2011) Consumer Search and Dynamic Price Dispersion: An Application to Gasoline Markets. RAND Journal of Economics, 42(2), 681-704. 
Meyer, J. and Cramon-Taubadel, S. (2004) Asymmetric Price Transmission: A Survey. Journal of Agricultural Economics, 55(3), 581-611.

Giulietti, M., Waterson, M. and Wildenbeest, M. (2014) Estimation of Search Frictions in the British Electricity Market. Journal of Industrial Economics, 62(4), 555-590.

Hortacsu, A., Madanizadeh, S.A. and Puller, S. (2015) Power to Choose? An Analysis of Consumer Inertia in the Residential Electricity Market. NBER Working Paper No. 20988.

Janssen, M. and Moraga-González, J.L. (2004) Strategic Pricing, Consumer Search and the Number of Firms. Review of Economic Studies, 71(4), 1089-1118.

Lewis, M.S. (2011) Asymmetric Price Adjustment and Consumer Search: An Examination of the Retail Gasoline Market. Journal of Economics \& Management Strategy, 20(2), pp.409-449.

Lewis, M.S. and Marvel, H.P. (2011) When do Consumer Search?, Journal of Industrial Economics, 49(3), pp.457-483.

Peltzman, S. (2000) Prices Rise Faster than They Fall. Journal of Political Economy, 108(3), pp. 466-502

Pennersdorfer, D., Schmidt-Dengler, P., Schutz, N., Weiss, C. and Yontcheva, B. (2014) Information and Price Dispersion: Evidence from Retail Gasoline. University of Vienna, Working Paper.

Ritz, R. A. (2015) The Simple Economics of Asymmetric Cost Pass-Through. Cambridge Working Paper in Economics, EPRG Working Paper 1511.

Sorensen, A.T. (2000). Equilibrium Price Dispersion in Retail Markets for Prescription Drugs. Journal of Political Economy, 108(4), 833-850. 
Stahl, D.O. (1989) Oligopolistic Pricing with Sequential Consumer Search. American Economic Review, 79(4), 700-712.

Stigler, G.J. (1961) The Economics of Information. Journal of Political Economy, 69(3), 213-225.

Tappata, M. (2009) Rockets and Feathers: Understanding Asymmetric Pricing. RAND Journal of Economics, 40 (4). pp.673-687.

Varian, H.R. (1980) A Model of Sales. American Economic Review, 70, 651-659.

Yang, H. and Ye, L. (2008) Search with Learning: Understanding Asymmetric Price Adjustments. RAND Journal of Economics, 39 (2), pp. 547-564. 


\section{Appendix}

\section{Figure 2: Screenshot of a Price Comparison Site (Toptarif.de)}

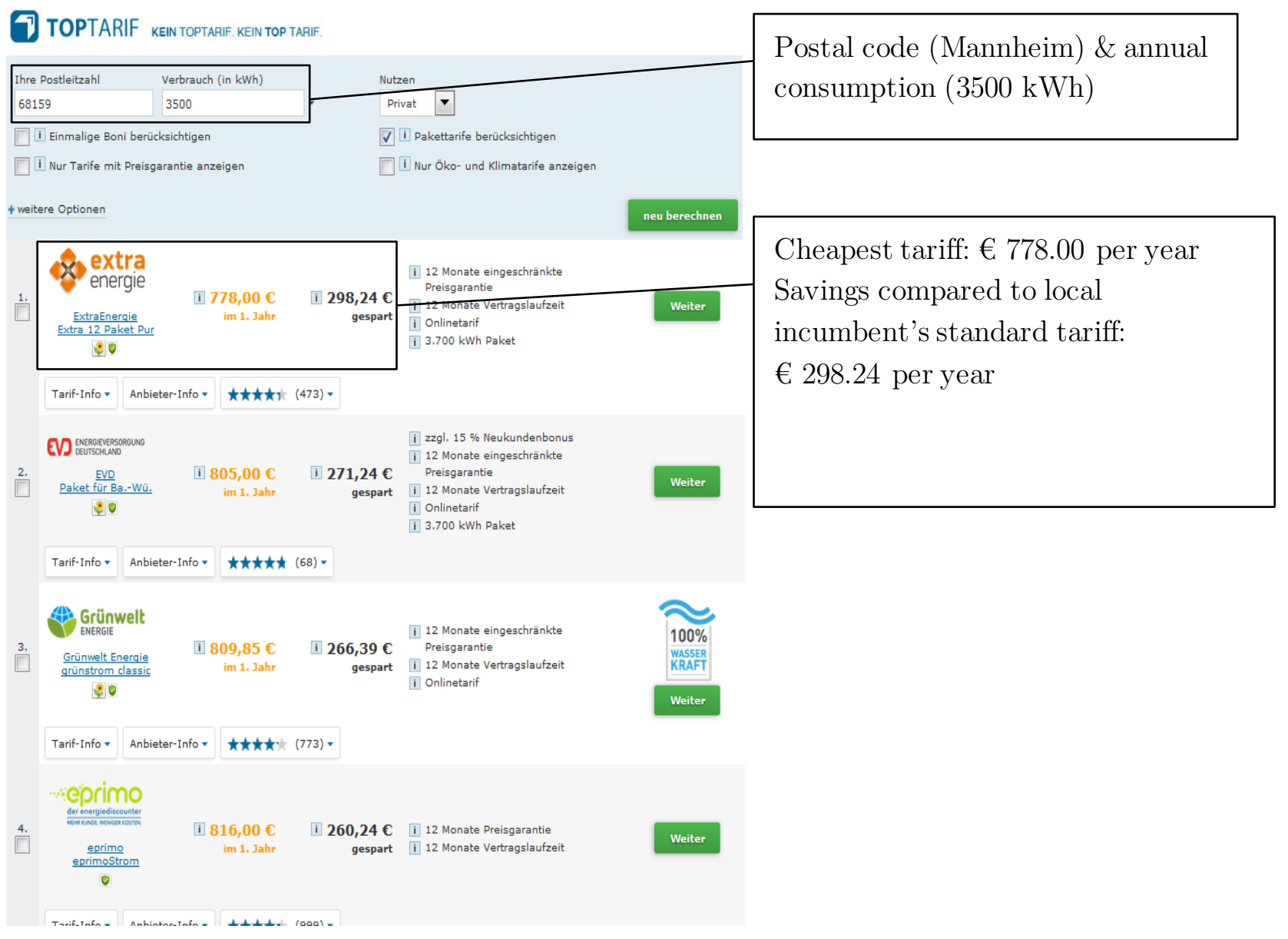


Figure 3: Spatial price distribution (2014)

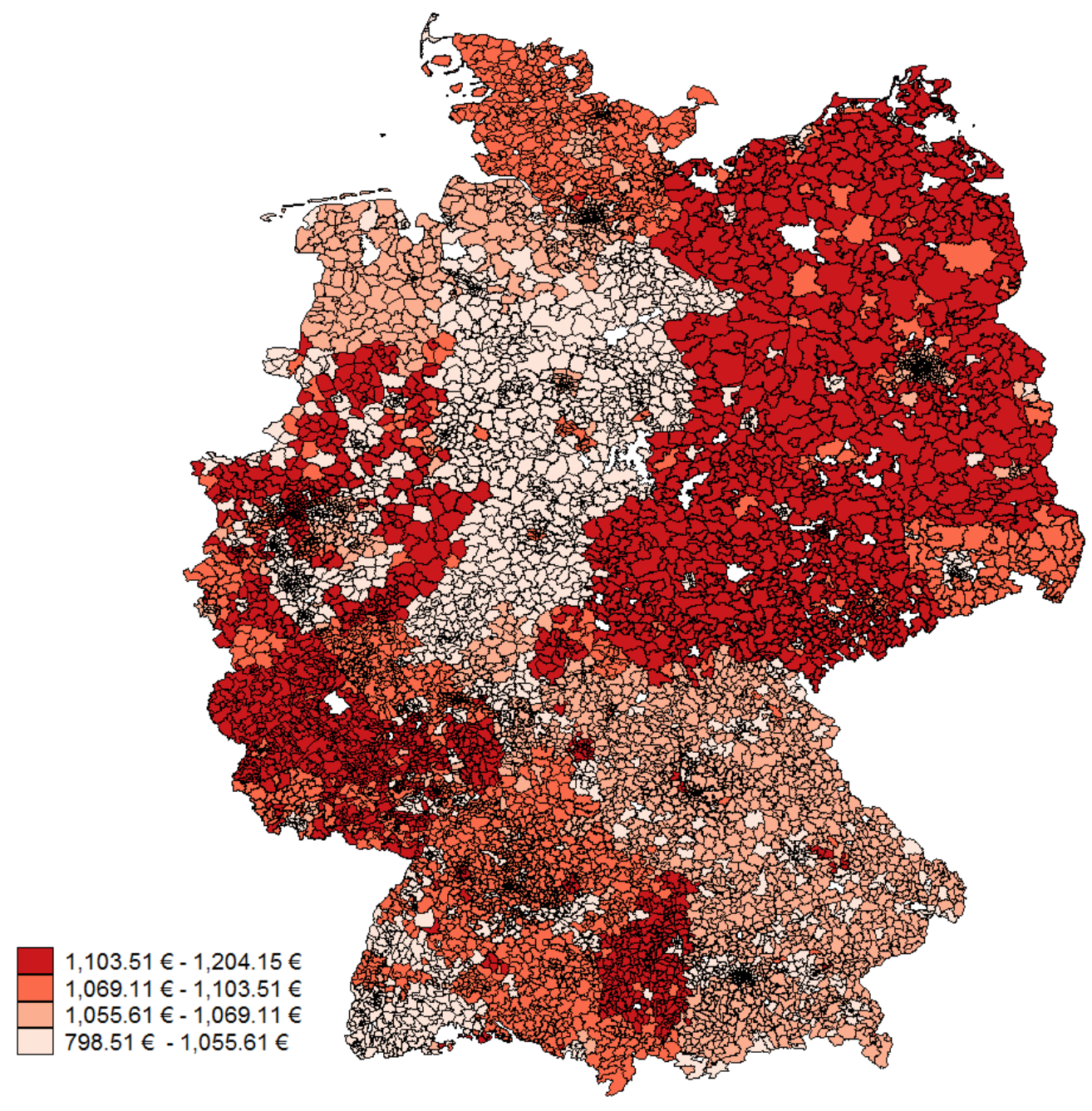


Figure 4: Spatial cost distribution (2014)

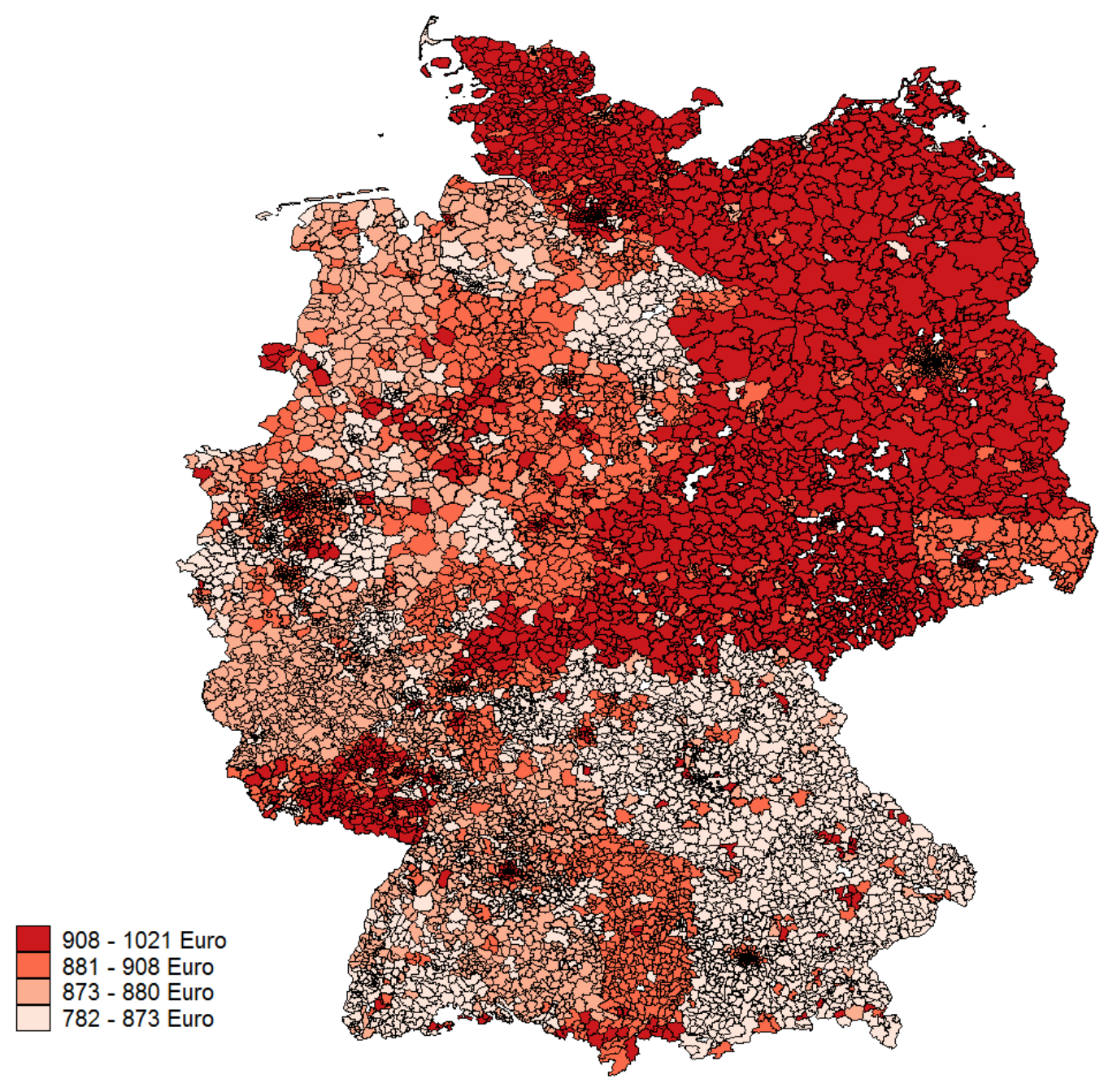


Figure 5: Spatial search intensity distribution (2014)

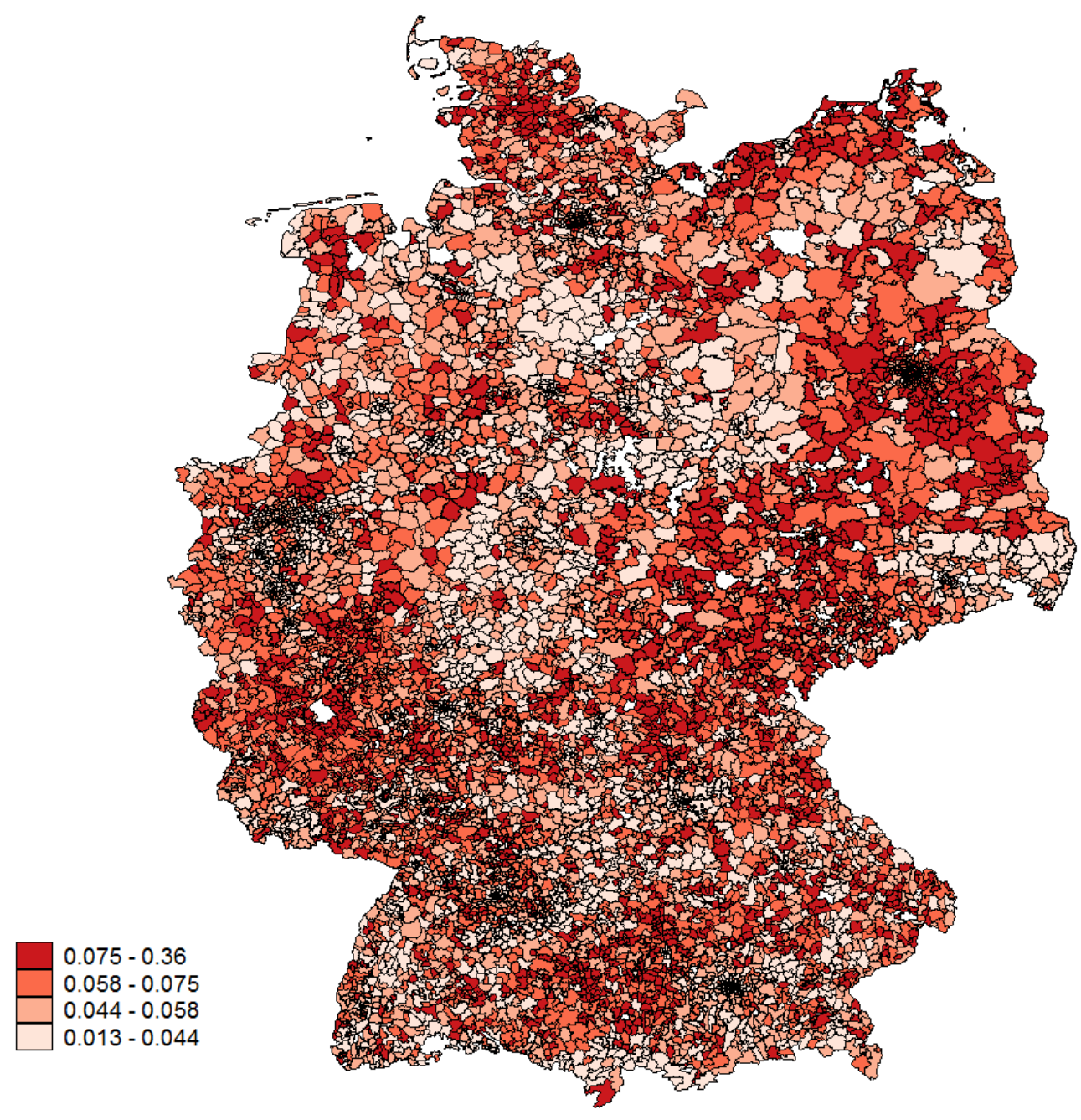


Figure 6: Distribution of total cost changes per year

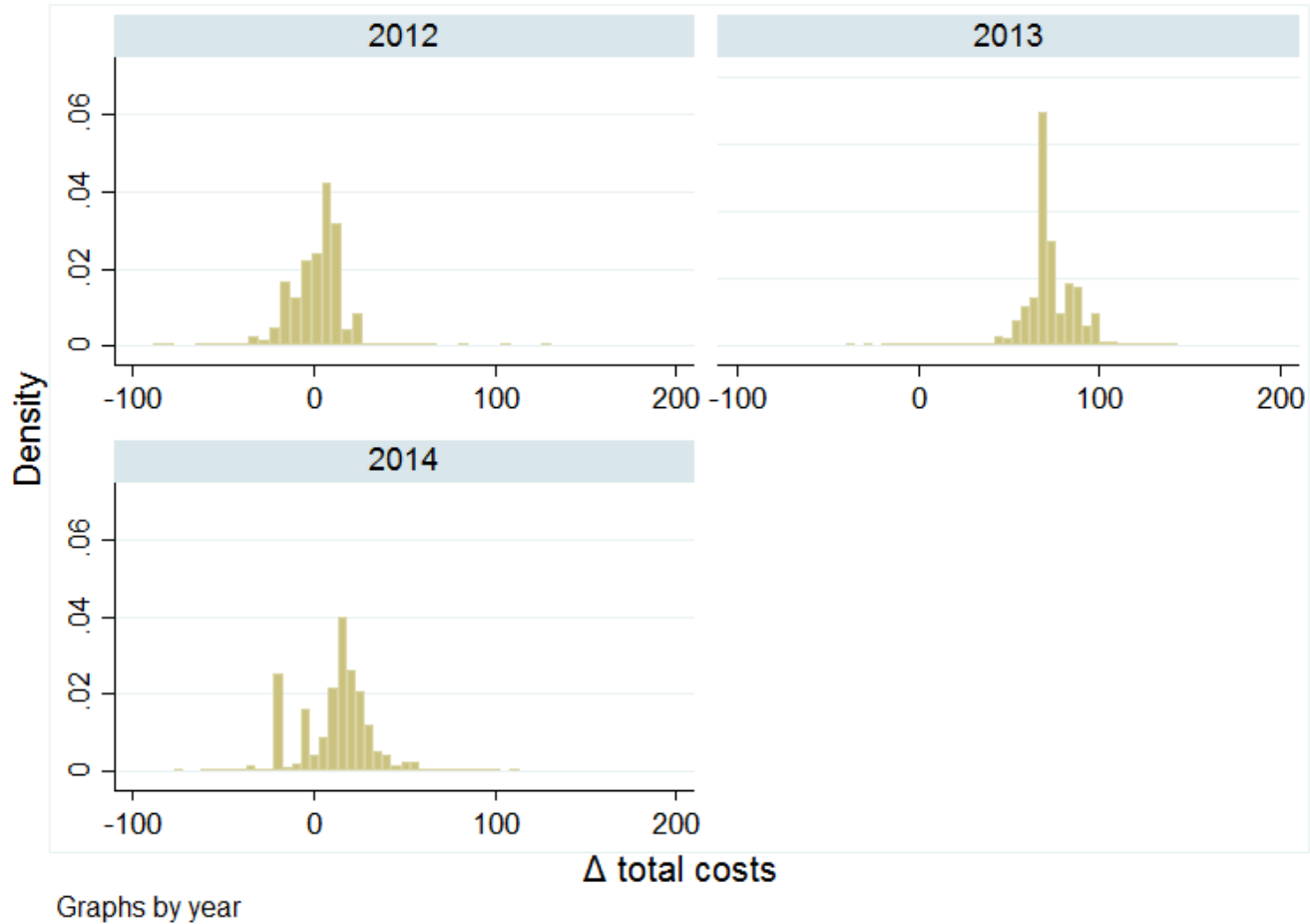

Figure 7: Distribution of locally varying cost changes per year

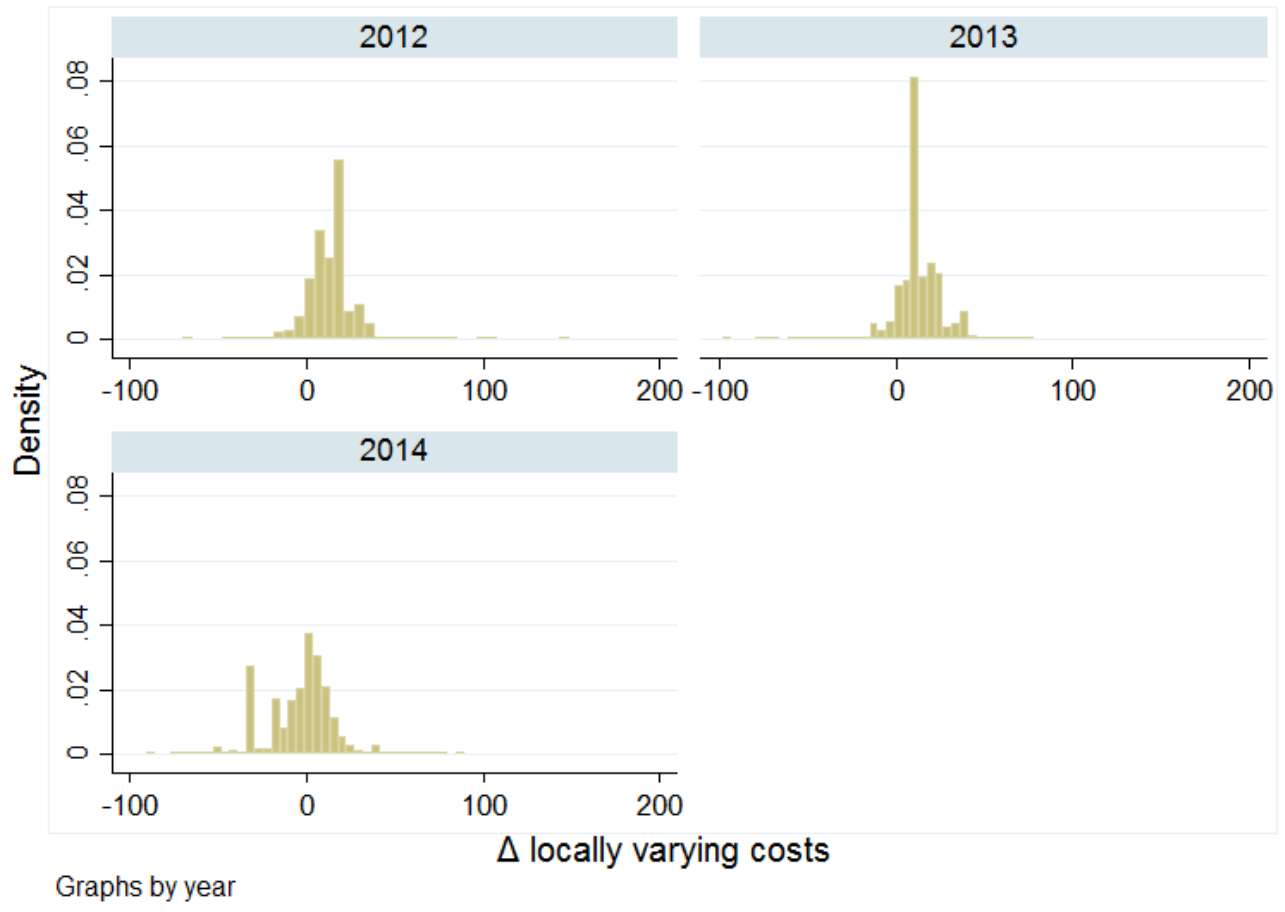

